\title{
sobre La narración perturbadora: un nuevo concepto narratológico transmedial, de Sabine Schlickers, con la colaboración de Vera TorO. Madrid/Frankfurt: Iberoamericana/Nervuert, 2017.
}

\author{
ANALÍA GERBAUDO Universidad Nacional del Litoral - CONICET, Argentina \\ agerbaudo@fhuc.unl.edu.ar/analia.gerbaudo@conicet.gov.ar
}

\section{La teoría y las mujeres}

Durante una conversación informal, un amigo que enseña teoría literaria en una universidad pública de Argentina cuyo nombre prefiero mantener en reserva, se despacha con una interpelación provocativa: «iviste que el campo de la teoría en nuestro país está dominado por las mujeres?». En un primer momento la conjetura me pareció exagerada. Luego, examinada desde una perspectiva histórica de largo plazo, la encontré plausible. En un listado incompleto aparecen los nombres de Ana María Barrenechea y su corrección de la definición otrora elaborada por Tzvetan Todorov para el género fantástico; Beatriz Sarlo y sus conceptos de «modernidad periférica» y «regionalismo no regionalista»; Josefina Ludmer y sus planteos respecto de los «modos de leer», los «cuentos» y la «postautonomía»; Sandra Contreras y su reformulación del «realismo»; Ana Camblong y su definición de «umbral semiótico»; Judith Podlubne y su noción de «moral humanista»; Rossana Nofal y su categoría "cuentos de guerra», Graciela Goldchluk y sus vueltas sobre el «archivo»; Susana Romano Sued y sus «aduanas del conocimiento»; Ana Teresa Martínez y sus «figuras mediadoras», Graciela Montaldo, sus «ficciones culturales» y sus «fábulas de identidad», entre otros.

Hace unos meses, durante el último congreso organizado por LASA (Latin American Studies Association) en Barcelona, Annaliza Mirizio lanza su concepto de «biblioteca del cineasta» y, en el mismo marco, Julieta Yelin hace lo propio con su noción de «biopoética». A ese movimiento se integra el concepto de «narración perturbadora» desarrollado por Sabine Schlickers en La narración perturbadora: un nuevo concepto narratológico transmedial, resultado de un trabajo de investigación financiado por la Universidad de Bremen.

Schlickers escribió este libro especialmente en español para su circulación en la comunidad hispanohablante: este gesto marca una toma de posición respecto de las geografías por las que le interesa que circulen sus trabajos que transitan varias lenguas entre las que se cuentan, además del alemán y del español, el inglés y el francés. Se trata de un gesto reafirmado por los lugares en

\footnotetext{
Para citar este artículo: Gerbaudo, Analía (2019). Sobre: La narración perturbadora: un nuevo concepto narratológico transmedial, de Sabine Schlickers, con la colaboración de Vera Toro. El taco en la brea, 9 (diciembremayo), 119-121. Santa Fe, Argentina: UNL. DOI: 10.14409/tb.v1ig.8195
} 
los que previamente Schlickers discutió versiones preliminares: Chile, Hamburgo, Buenos Aires, Viena, Lille y Santa Fe. En cada uno de esos lugares hay un equipo con el que Schlickers trabaja: en ese sentido cabe mencionar los envíos a los desarrollos de otro productor de categorías teóricas: Gonzalo Aguilar. Referencia obligada en una investigación que articula el cine con la literatura, la historieta y el teatro para proponer un nuevo concepto dentro de la reivindicada línea «estructuralista»: «el presente estudio persigue un objetivo estructuralista: queremos (re) modelizar y sistematizar aquellos recursos narrativos que constituyen una narración perturbadora y presentar su funcionamiento interactivo» (Schlickers:17-18).

Este texto participa y toma posición respecto de tres tensiones del campo de la investigación literaria.

La primera tensión se liga al corpus: conocedora de las discusiones del campo cultural argentino y, tal como lo ha manifestado en muchas de sus clases, tanto en Alemania como en Argentina (Schlickers ha dado clases abiertas de Teoría literaria I para los estudiantes de letras de la Universidad Nacional del Litoral así como nosotros participamos de las suyas en la Universidad de Bremen), sus construcciones no se alinean con las alzas y bajas de la bolsa de valores local de la crítica literaria. Alguien podría observar que, si en sus textos caen juntos Una mujer sin cabeza de Lucrecia Martel con Rayuela de Julio Cortázar (o mejor aún: Rayuela junto a Los topos de Félix Bruzzone) es debido a lo que dichos textos presentan en términos de estructuras narrativas. Si se va despacio en la lectura se podrá observar que, mientras retoma dichos textos para desagregar las diferentes variantes de la narración perturbadora (una combinación de recursos de las estrategias «engañosa», "paradójica» y/o «estigmatizante»), deja entrever una toma de posición que va más allá: Schlickers anuda ciertas operaciones de escritura con una valoración de los textos inescindible de cierta «sofisticación», sin caer en la moral que pretende dictaminar qué cosa sería la «buena literatura». En este sentido, vale la pena recobrar una conversación con un estudiante que Schlickers evoca casi al cierre de la introducción de su libro: «Una estudiante de Erasmus nos dijo al final de un seminario sobre la narración perturbadora que aprendió muchísimo porque esta "te explica el mecanismo de la buena literatura"» (31). Schlickers trae la anécdota, justamente, para desmarcarse de dicha posición: "Dudamos de que la "buena literatura" consista en un mecanismo que haya que descubrir, pero al menos creemos haber encontrado una modelización apta para describir y tipificar aquellos recursos narrativos sofisticados cuya interacción produce una narración perturbadora» (31). Y finalmente agrega, incluyendo en la enunciación a Vera Toro: «Nos daremos por satisfechas si en las siguientes páginas logramos transmitir algo de nuestro entusiasmo por la "buena literatura" y el "buen cine", ya que la narración perturbadora consta de textos artísticos muy originales, sofisticados y polisémicos» (31).

La segunda tensión comprende la reactualización de la narratología: una teoría que en Alemania y en Francia da lugar a programas de investigación y alrededor de la cual se siguen produciendo revistas, libros y activos grupos que organizan congresos específicos y redes de cooperación. En consecuencia, quisiera destacar que nos encontramos aquí con una exhaustiva elaboración categorial que, por su detalle y minuciosidad, nos recuerda a libros del tipo de Palimpsestes de Gérard Genette. Es decir: se trata de un libro que precisa tres diferentes estrategias de construcción de la narración perturbadora desagregando, para cada una, sus recursos y operaciones específicas. El enorme corpus fílmico y literario utilizado sirve para ejemplificar cada una de las categorizaciones que Schlickers propone mientras, como en un «bucle extraño» (Hofstadter), funcionó como 
disparador del armado conceptual. Se trata, en términos cuantitativos, de un trabajo de casi 500 páginas: estamos ante el desarrollo obsesivo e imponente de un concepto que reúne todas las características necesarias para incorporarse a los que la narratología ha estabilizado.

La tercera tensión abarca la controversial práctica de la producción categorial. Sin lugar a dudas puede decirse que el aporte central del texto de Schlickers consiste en su formulación conceptual: su noción de "narración perturbadora». Se trata de un gesto osado, más practicado que reconocido como tal, aunque algunos episodios más o menos recientes manifiestan otros agenciamientos: se puede observar la reafirmación de una posición de producción teórica en la reciente decisión de Clara María Parra Triana y de Raúl Rodríguez Freire (2018) de editar una segunda versión ampliada de su antología de teoría y crítica cultural producida desde América Latina. Se podrá encontrar en uno de los últimos libros publicados en español por Gonzalo Aguilar (2015) el desarrollo de categorías que vuelven, en parte, sobre un fenómeno al que estoy aludiendo. Aguilar aporta conceptos que permiten describir cómo viajan las producciones artísticas y culturales en general. Aguilar caracteriza estos movimientos a partir de una inscripción geopolítica: llama «limítrofes» a los cosmopolitismos desarrollados entre las periferias y «marginales», a nuestros usuales desplazamientos hacia los centros metropolitanos de Estados Unidos y Europa occidental. Traigo estas referencias a las que agrego las de las mujeres que cité al inicio de esta reseña para subrayar el gesto, para algunos «inquietante», de inscribir las formulaciones producidas desde las periferias como producción categorial. Un gesto que quisiera subrayar a propósito de Schlickers, empeñada en discutir los resultados de sus investigaciones con investigadores del Sur. Sus prácticas dan cuenta de un flujo de circulación Sur-Norte sostenido desde hace ya veinte años. También dan cuenta de un movimiento de reafirmación de la potencia de la producción categorial, con sello de mujer.

\section{Referencias bibliográficas}

Aguilar, G. (2015). Más allá del pueblo. Imágenes, indicios y políticas del cine. Buenos Aires: Fondo de Cultura Económica.

Hofstadter, D. (1979). Gödel, Escher, Bach. Un Eterno y Grácil Bucle. Barcelona: Tusquets, 1987. Traducción de Mario Usabiaga y Alejandro López Rousseau.

Parra Triana, C. y R. Rodríguez Freire (2018). Crítica literaria y teoría cultural en América Latina. Para una antología del siglo XX. Valparaíso: Ediciones Universitarias de Valparaíso. 